\title{
PENYULUHAN DAN PEMBERIAN MATERI DAN DEMO / PRAKTEK PELATIHAN SALON KECANTIKAN KHUSUS MAKE UP WAJAH SEDERHANA DENGAN KONSENTRASI PADA PENGELOLAAN SUMBER DAYA MANUSIA
}

\author{
${ }^{1}$ Whina Ratnawati, ${ }^{2}$ Angga Pratama, ${ }^{3}$ Anisa Nurdina, \\ ${ }^{4}$ Rio Setiawan, ${ }^{5}$ Wahadi Siamto \\ ${ }^{1,2,3,4,5}$ Dosen Fakultas Ekonomi Prodi Manajemen Universitas Pamulang \\ Email : ${ }^{1}$ dosen02057@unpam.ac.id, ${ }^{2}$ dosen02155@unpam.ac.id, ${ }^{3}$ dosen01007@unpam.ac.id, ${ }^{4}$ \\ dosen02059@unpam.ac.id, ${ }^{5}$ dosen01458@unpam.ac.id
}

\begin{abstract}
Implementation of Community Service is one of the applications of the Tri Dharma of Higher Education which in its implementation makes a positive contribution tosociety. The implementation of this PKM takes the title "Penyuluhan dan pemberian materi dan demo / praktek pelatihan salon kecantikan khusus make up sederhana dengan konsentrasi pada pengelolaan Sumber Daya Manusia“. The location chosen was an orphanage located in the Ciater Serpong area, South Tangeerang City. Where this location has small businesses that still require better human resource management. The method used in the implementation of this PKM is a workshop or training. Where previously the direct observation stage was carried out to find out the problem. That appears at the research location. This training is used to provide an in-depth understanding of human resource management, especially human resource management in small businesses that have been initiated, it is intended that the Orphanage Al-Amien, who consists of caregivers and children, can understand and implement human resource management quite well. In addition to the training on human resource management, on this occasion an explanation was also given about the basics of entrepreneurship and Her specialty salon business is simple makeup. The results of Community Service went very smoothly and all participants who attended were sure to get a pretty good understanding of the material. On At the end of the training session the participants were also given simple practices to support the ability to implement human resource management in small businesses that are already running at the Al-Amien Ciater Orphanage. As a refinement and ensure the ability of participants In applying the material optimally, there will be periodic evaluation stages from a team of lecturers and PKM teaching practitioners.
\end{abstract}

Keywords: Ilumination, Human resource management

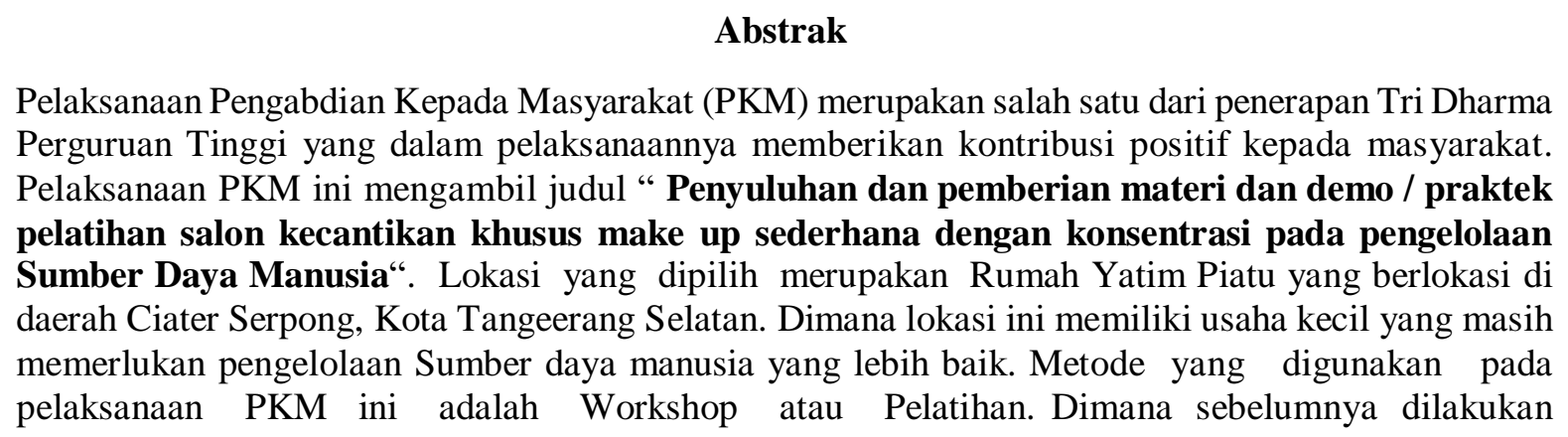


tahapan observasi langsung guna mengetahui permasalah yang muncul pada lokasi penelitian. Pelatihan ini digunakan

untuk untuk memberikan pemahaman mendalam tentang manajemen sumber daya manusia khususnya pengelolaan sumber daya manusia pada usaha kecil yang sudah dirintis, hal ini bertujuan agar Rumah Yatim Piatu Al-Amien yang terdiri dari pengasuh dan anak - anak dapat memahami dan menerapkan pengelolaan sumber daya manusia dengan cukup baik. Selain Pelatihan Pengelolaan sumber daya manusia pada kesempatan ini sekaligus diberikan penjelasan tentang dasar - dasar Wirausaha dan Usaha salon khusus nya make up sederhana. Hasil Pengabdian Kepada Masyarakat ( PKM ) berjalan dengan sangat lancar dan seluruh peserta yang hadir dipastikan mendapatkan pemahaman materi dengan cukup baik. Pada akhir sesi pelatihan peserta diberikan juga praktek sederhana guna menunjang kemampuan implementasi pengelolaan sumber daya manusia pada usaha kecil yang sudah berjalan di Rumah Yatim Piatu Al-Amien Ciater ini. Sebagai penyempurnaan dan memastikan kemampuan peserta dalam menerapkan materi secara maksimal, akan dilakukan tahapan evaluasi secara berkala dari tim dosen dan praktisi pengajar PKM.

\section{Kata Kunci: Penyuluhan, Pengelolaan sumber daya manusia}

\section{A. PENDAHULUAN}

Pada awal tahun 2020, tepatnya bulan maret sampai saat ini di Indonesia mengalami adanya wabah Virus corona( Covid 19). Hal ini berdampak pada semua sektor, terutama perekonomian di Indonesia. Banyak perusahaan dan usaha kecil yang mengalami kebangkrutan dan kerugian. Hal ini berdampak pada pengurangan jumlah karyawan(PHK) secara serentak. Banyak karyawan yang dirumahkan sehingga berdampak dalam perekonomian dan pendapatan mereka. Situasi ini memicu seseorang untuk bisa bertahan hidup dalam segala kondisi dan situasi yang mereka alami.

Permasalahan yang tengah menggurita dalam kehidupan bermasyarakat di Indonesia tidak saja merupakan tanggung jawab Pemerintah akan tetapi juga sudah menjadi tanggung jawab seluruh bangsa Indonesia. Karenanya yang dibutuhkan saat ini adalah solusi yang dapat membantu dalam mengatasi permasalahan yang telah diuraikan di atas. Secara sederhana dapat dikatakan bahwa salah satu solusi yang dapat dilakukan untuk dapat keluar dari masalah terumit yang dihadapi pemerintah saat ini adalah dengan menumbuhkan dan membentuk karakter kewirausahaan sosial pada setiap lapisan indidvidu di masyarakat, terutama generasi muda yang merupakan tulang punggung bangsa (Ayob et.al., 2013; Utomo, 2014; Reginald dan Mawardi, 2014; Sofia, 2015).

Kebutuhan akan tenaga kerja yang berkualitas dalam era kompetitif dewasa ini harus diimbangi dengan terciptanya wirausahawan yang berkualitas, sehingga dengan semakin banyaknya jumlah wirausahawan yang berkualitas, maka jumlah lapangan kerja dan pendapatan ekonomi masyarakat pun ikut meningkat dan dengan sendirinya berdampak pada menurunnya jumlah pengangguran (Reginald dan Mawardi, 2014). Keinginan berwirausaha pada individu berperan penting untuk membangun niat dalam diri untuk melakukan wirausaha sosial (Ayob, et.al. 2013).

Pentingnya kegiatan wirausaha pada rumah yatim piatu ditujukan agar anak 


\begin{abstract}
panti
asuhan dan seluruh pengelola dapat memiliki kemampuan untuk mengelola sumber daya manusia yang baik dan kemandirian dalam berwirausaha. Hal tersebut disiapkan sejak dini dari awal dimulainya kegiatan wirausaha agar kedepannya kemampuan ini dapat mendukung

proses berwirausaha dengan sangat maksimal dan tepat perhitungan sehingga usaha yang ditekuni dapat berkembang terus menerus dari waktu ke waktu.
\end{abstract}

Berdasarkan pada hal tersebut diatas maka akan dilaksanakan Pengabdian Kepada Masyarakat (PKM) di Rumah yatim piatu Al-Amiin, Ciater Kota Tangerang Selatan. Dimana saat ini anak - anak panti asuhan Al - Amiin sudah memulai merintis usaha secara bersama - sama guna mengajarkan dan mendidik kemandirian. Usaha yang saat ini mulai dirintis bergerak dibidang makanan yakni kantin. Rintisan usaha tersebut masih dikelola secara sederhana oleh anak - anak panti asuhan dengan manjemen pengelolaan yang sudah baik dan masih bersifat rutinitas, terutama mengenai pentingnya pengelolaan Sumber Daya Manusia. Maka dari itu kami tim dosen dari keahlian sumber daya manusia akan memberikan pelatihan tutorial make up sederhana khususnya untuk acara wisuda.

\section{B. METODE PELAKSANAAN KEGIATAN}

Mekanisme tahapan kegiatan Program Kemitraan Masyarakat (PKM) terdiri atas enam tahapan, yakni tahap persiapan, investigasi, pembekalan, praimplementasi, evaluasi, dan implementasi. Pada tahapan persiapan dilakukan survey lokasi dan koordinasi dengan mitra. Pada tahapan investigasi yang dilakukan adalah menggali komponen-komponen permasalahan yang tengah dihadapi mitra, mendengarkan berbagai keluhan mitra dalam menjalankan usahanya serta keinginan dan harapan mitra terhadap wirausaha yang tengah dirintisnya. Pada tahapan investigasi ini juga dilakukan identifikasi produk yang dimiliki mitra, menggali keterampilan, manajemen usaha, kegiatan administrasi dan pembukuan yang dimiliki mitra dan telah dijalankan dalam berwirausaha serta kegiatan promosi yang telah dilakukan.

Selain itu, pada tahapan investigasi ini juga akan digali potensi dan ide kreatif dari mitra yang belum terealisasi dan termanfaatkan. Sementara itu, tahapan pembekalan dibagi menjadi beberapa bagian, yaitu pembekalan pengembangan pembuatan produk unggulan melalui inovasi kemasan minuman, pembekalan pelatihan manajemen usaha, pembekalan sistem administrasi dan pembekalan penyusunan laporan keuangan sederhana, serta pembekalan perluasan jaringan pemasaran produk.

Sementara itu, pada tahap praimplementasi dilakukan penerapan ilmu pengetahuan dan keterampilan yang telah diperoleh selama tahapan pembekalan. Pada tahapan ini juga digunakan untuk mengetahui nilai tambah dari kegiatan pengabdian PKM yang telah dilakukan. Pada tahapan ini dapat diketahui apakah masih terdapat hal-hal yang perlu untuk diperbaiki dan bagaimana cara penerapannya. Selanjutnya, pada tahap evaluasi dilakukan evaluasi hasil pra implementasi serta kendala-kendala yang dihadapi untuk dijadikan dasar dalam melakukan perbaikan.

Terakhir adalah tahapan implementasi yang merupakan penerapan secara berkelanjutan ilmu pengetahuan dan keterampilan yang telah diperoleh selama kegiatan pengabdian PKM berlangsung. Implementasi ilmu pengetahuan dan 
keterampilan yang diterapkan secara berkelanjutan diharapkan dapat mengembangkan kelompok masyarakat Panti Asuhan Al-Amanah menjadi mandiri secara ekonomi dan sosial, membantu menciptakan ketentraman, kenyamanan dalam kehidupan bermasyarakat, dan meningkatkan keterampilan dalam berwirausaha.

Pendekatan yang dilakukan untuk menyelesaikan persoalan mitra meliputi pendekatan partisipatif, metode pendekatan ceramah, pendekatan FGD (Focus Group Discussion), pendekatan kelompok dan individual.

A. Metode Pendekatan Partisipatif. Metode ini digunakan agar mitra dapat berpartisipasi aktif terhadap seluruh rangkaian kegiatan yang akan dilaksanakan. Pendekatan ini diawali dengan kegiatan bertemu secara langsung dengan pelaku usaha yang telah sukses. Hal ini dilakukan untuk memberikan motivasi, inspirasi, membangun niat, menumbuhkan semangat mitra untuk terus melakukan inovasi pengembangan usaha serta mengikuti dengan seksama proses kegiatan Program Kemitraan Kemasyarakatan (PKM).

B. Metode Pendekatan Ceramah. Cara yang paling efektif untuk memperkenalkan informasi atau konsep-konsep yang baru pada sekelompok orang yang belajar. Dalam metode pendekatan ini dilakukan presentasi mengenai konsep dan informasi dalam cara yang sistematis dalam waktu yang terbatas, menggunakan alat bantu, berdiskusi dengan mitra.
C. Metode Pendekatan FGD (Focus Group Discussion). Pada metode ini dilakukan sharing pengalaman dalam proses pembelajaran dengan cara: (a) Memberikan kesempatan kepada mitra untuk saling berbagi pengalaman, gagasan, ide, dan mengklarifikasi sudut pandang mitra yang berbeda (b) Membantu mitra mengenali apa yang mereka telah lakukan dan hal-hal yang mitra tidak ketahui (c) Membantu mitra menjawab pertanyaanpertanyaan yang selama ini mereka temui dalam pengalaman, meningkatkan keterlibatan mitra dalam menajalankan usahanya.

D. Pendekatan Kelompok dan Individual. Dalam metode pendekatan kelompok dan individual ini digunakan pembelajaran dengan melakukan pembelajaran melalui pengamatan. Hal-hal yang dilakukan adalah dengan pelatihan pengelolaan sistem administrasi, pelatihan penyusunan laporan keuangan sederhana, pelatihan pembuatan web/media sosial lainnya untuk kegiatan promosi. Di setiap akhir pelaksanaan kegiatan mitra diberikan angket untuk mengetahui seberapa besar tingkat pemahaman terhadap materi dan program yang telah diberikan.

\section{HASIL DAN PEMBAHASAN}

\section{HASIL}

Pada pelaksanaan kegiatan PKM ini di awal kedatangan tim disambut oleh segenap pengurus dan ketua Yayasan, dilanjutkan dengan penandatanganan kerja sama PKM oleh ketua Yayasan dan Ketua tim PKM. Pelaksanaan kelas dihadiri oleh peserta yang terdiri dari anak- anak asuh untuk usia pendidikan SMP, SMK dan pengurus Yayasan yang berkecimpung dalam kegiatas usaha kecil yang dikelola oleh 
Rumah

Yatim Piatu Al- Amien Ciater ini. Team Dosen terdiri dari ${ }^{1}$ WHINA RATNAWATI, ${ }^{2}$ ANGGA PRATAMA, ${ }^{3}$ ANISA NURDIANA, ${ }^{4}$ RIO SETIAWAN, ${ }^{5}$ WAHADI SIAMTO.

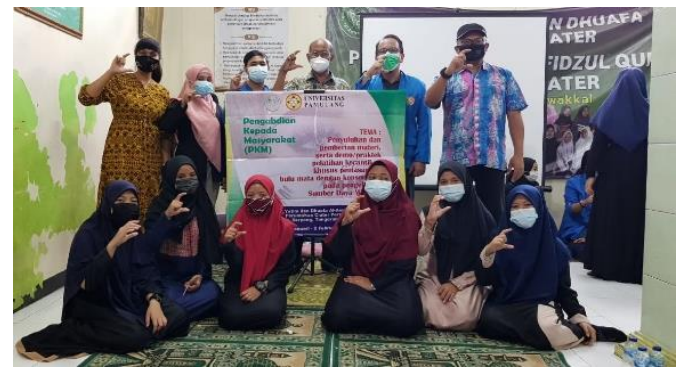

Hasil kegiatan yang digunakan kepada peserta yang hadir dan pengelola Rumah Yatim Piatu Al- Amien adalah dengan memberikan penjelasan materi teori terlebih dahulu baru kemudian peragaan dengan menggunakan media yang sudah disiapkan untuk pengelolaan sumber daya manusia sederhana di usaha kecil dan pengamatan proses.

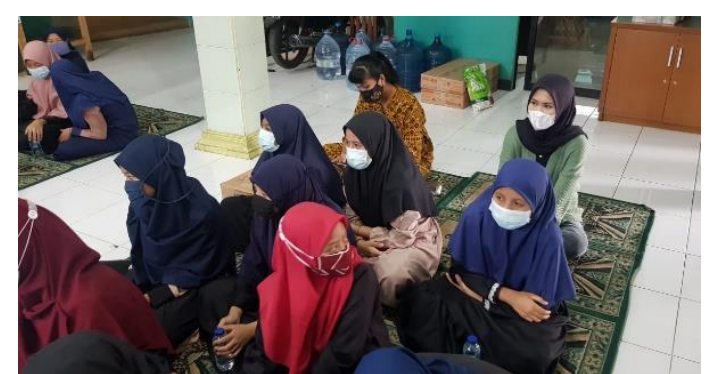

Secara keseluruhan peserta memahami konsep Wirausaha dan dasar - dasar kewirausahaan sehingga memotivasi semua peserta untuk terlibat dalam kegiatan usaha. Selain itu peserta dapat juga memahami teknik sumber daya manusia yang baik guna mendukung usaha kecil yang sudah berjalan. Hal tersebut dapat dilihat dari hasil test tertulis kepada peserta yang hadir dimana diperoleh data berikut :

1. Sebanyak $93 \%$ peserta mendapatkan nilai Post test maksimal
2. Sebanyak $87 \%$ peserta dapat menerapkan praktek dengan maksimal gunapengelolaan sumber daya manusia memakai form yang disediakan

3. Pada pelaksanaan tanya jawab $97 \%$ peserta antusias dan dapat saling memberikan feedback dan motivasi.

Selain berkaitan dengan Manajemen atau pengelolaan Sumber daya manusia dalam Usaha kecil, peserta juga dipastikan sudah dapat memahami dengan baik dasar Wirausaha dan kewirausahaan seperti :

1. Memahami Mekanisme pelaksanaan Make up standar

2. Memahami hal - hal yang wajib dilakukan oleh para pengusaha salon

3. Memahami Dasar manajemen atau pengelolaan salon

4. Memahami tujuan dan manfaat mengelola SDM di usaha salon

Selanjutnya Rumah Yatim Piatu bersama dengan anak - anak asuh dan pengurus akan menjalankan konsep pengelolaan sumber daya manusia yang sudah didapatkannya dengan panduan dan arahan secara berkala oleh tim dosen. Pada pelaksanaan akan dilakukan evaluasi oleh tim PKM.

Berikut ini adalah tahapan kegiatan dari pelaksanaan yang sudah dilakukan selama kegiatan PKM berlangsung :

\section{Tahap Persiapan}

Adapun tahap-tahap yang dilakukan dalam kegiatan ini meliputi:

a. Survei awal

Pada tahap ini dilakukan survei ke lokasi Pengabdian Kepada

Masyarakat ( PKM ) di Rumah Yatim Piatu Al- Amien.

b. Fiksasi Jadwal 
Pada tahap

ini dilakukan penentuan waktu kegiatan.

\section{c. Persiapan Materi Kegiatan}

Pada tahap ini dilakukan penyusunan materi pelatihan untuk kegiatan yang meliputi: Slide, Handout, dan buklet.

\section{d. Persiapan Peragaan.}

Pada tahap ini seluruh tim PKM mempersiapkan alat dan bahan untuk peragaan tutorial make up sederhana.

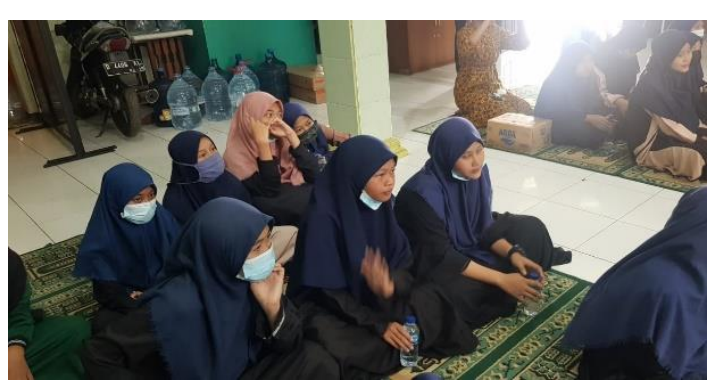

Tahap Pelaksanaan Kegiatan.

Untuk melaksanakan kegiatan ini digunakan 3 metode, yaitu:

a. Metode Penjelasan Teori

Memberikan penjelasan singkat dan sederhana tentang Wirausaha dan manajemen atau pengelolaan sumber daya

manusia pada usaha kecil yang sudah dirintis

\section{b. Metode Peragaan}

Mengarahkan dan memandu proses tutorial make up sederhana untuk acara wisuda dengan menggunakan alat dan media yang sudah disediakan.

\section{c.Diskusi}

Melakukan kegiatan diskusi dengan pengelola Yayasan Rumah Yatim Piatu AlAmien dan memandu pelaksanaan manajemen sumber daya manusia dan membuka wawasan

\section{PEMBAHASAN}

Manajemen SDM merupakan sekumpulan rencana pengembangan, perbaikan dan evaluasi karyawan agar menjadi lebih baik. Dengan kinerja karyawan yang lebih baik, bisnis yang kecil pun bisa memberikan hasil yang besar. Namun untuk mencapai tujuan itu, diperlukan Manajemen SDM untuk usaha kecilyang baik dan terarah.

Langkah-langkah manajemen Sumber Daya Manusia untuk memajukan usaha kecil:

1. Pilih jenis usaha, langkah pertama yang harus anda lakukan adalah menentukan usaha yang pas dan cocok untuk anda. Cobalah pilih usaha yang sesuai dengan hobi atau hal yang anda sukai.

2. Manfaatkan peralatan yang dimiliki, ketika akan memulai merintis usaha tidak selamanya anda membutuhkan peralatan yang baru dan canggih. Anda bisa menggunakan peralatan yang dimiliki terlebih dahulu untuk meminimalisir modal yang keluar. Dan jika nanti usaha anda sudah besar dan alat yang ada sudah tidak memungkinkan, anda baru bisa membeli peralatan yang baru dan lebih canggih.

3. Pilihlah lokasi yang tepat, lokasi merupakan salah satu aspek penting dalam memulai usaha. Dengan memilih lokasi ramai dan tepat bisa membuat usaha anda lebih cepat berkembang. Untuk usaha yang baru dirintis, jangan ragu-ragu untuk memanfaatkan ruangan sekitar rumah yang adaseperti teras atau garasi rumah.

4. Manfaatkan social media, anda dapat memanfaatkan kecanggihan sosial media saat ini, karena dengan social media, anda bisa melakukan promosi secara gratis dan menjangkau lebih banyak calon pelanggan hingga keluar pulau dan negeri.

5. Menggunakan modal dengan bijak, hindari membeli barang-barang yang dirasa belum dibutuhkan. Karena modal 
Layalitas Kreativitas

Aldi Masyarakat Kreatif
P-ISSN 2722-2101, E-ISSN 2722-4201

Program Studi Ekonomi Manajemen Universitas Pamulang Jurnal LOKABMAS Kreatif Vol.02,No.02.Juli 2021 Hal.35-43

Email:jurnalkreatif.manajemen@gmail.com yang

dimiliki tidaklah banyak, sehingga jangan sampai modal sudah habis hanya untuk membeli barang-barang yang tidak begitu penting dalam usaha. Agar lebih aman, anda bisa membuat rencana belanja secara lengkap dan terperinci. Agar nantinya tidak salah langkah membelanjakan modal usaha.

6. Libatkan orang terdekat, Libatkan orang-orang disekitara anda seperti: suami, adik, kakak, saudara, sahabat dalam memulai usaha. Karena dengan mengajak orang terdekat tersebut pastinya tidak akan banyak menuntut kepada anda. Nantinya jika usaha yang dirintis sudah berkembang dan besar, anda bisa merekrut karyawan dari luar dengan beberapa kriteria yang bisa anda tentukan sendiri.

7. Pandai dalam membagi waktu, dalam mengembangkan usaha anda dituntut untuk bisa memanfaatkan dan menggunakan waktu secara tepat, efektif, efisien, dan menguntungkan. Bila perlu anda bisa melakukan timeline 1 bulan kedepan mengenai apa saja yang harus dilakukan, sehingga tidak ada waktu yang terbuang sia-sia.

8. Selalu lakukan inovasi produk, pada dasarnya para konsumen memiliki sifat cenderung lebih bosan, mereka menginginkan produk dengan inovasi baru. Jika konsumen sudah bosan pastinya konsumen akan pindah ke lain tempat yang dirasa lebih menarik dari sebelumnya.

9. Jadilah yang terbaik, dalam menjalankan usaha jangan pernah setengah-setengah. Setiap hal yang dilakukan anda harus memiliki keyakinan yang kuat. Apapun yang anda jual haruslah yang terbaik, jika anda kalah dengan kompetitor usaha yang sejenis, anda bisa masuk kedalam nya dengan membeli produknya atau menggunakan jasanya, kemudian pelajari apa bedanya dengan usaha yang anda lakukan, kemudian anda tinggal melakukan modifikasi dan diterapkan dalam usaha anda.

10. Rencanakan keuangan dengan baik, ketika usaha sudah mulai berjalan dan menghasilkan keuntungan, anda harus mulai pintar-pintar mengatur keluar masuknya uang dengan benar. Pisahkan antara uang milik pribadi dengan uang hasil usaha. Sudah banyak beberapa usaha yang gagal karena kesalahan dalam pengelolaan keuangan, antara uang pribadi dan usaha yang tercampur menjadi satu, sehingga keuangan usaha tidak bisa dimonitor apakah ada keuntungan atau kerugian.

\section{Tujuan Pengelolaan Sumber Daya Manusia Usaha Kecil}

Ada beberapa tujuan dari pengelolaan sumber daya manusia:

1. Untuk mengembangkan efektivitas kerja sumber daya manusia di dalam organisasi.

2. Memperbaiki kualitas tenaga kerja dalam suatu organisasi sehingga dapat memberikan kontribusi lebih kepada organisasi.

3. Memberikan aturan kerja yang efektif dengan produktivitas tinggi kepada organisasi.

4. Untuk menyeimbangkan antara tujuan masing-masing individu dan menyelaraskan nya hingga mampu bergerak dalam irama yang sama demi mencapai tujuan bersama yaitu tujuan perusahaan.

5. Untuk membantu para manajer fungsional dan manajer lini dalam mengelola seluruh tenaga kerja atau karyawan selaku sumber daya manusia dengan cara yang lebih efektif.

\section{KESIMPULAN DAN SARAN}

\section{KESIMPULAN}

Kegiatan Pengabdian Kepada Masyarakat (PKM) dengan judul : "Penyuluhan dan 
pemberian materi dan demo / praktek pelatihan salon kecantikan khusus make up wajah sederhana dengan konsentrasi pada pengelolaan sumber daya manusia". Secara keseluruhan berjalan dengan sangat lancar dan tertib. Peserta yang terdiri dari anak asuh dan pengurus Rumah Yatim Piatu sangat antusias dalam menyimak penjelasan materi, teori dan peragaan yang diberikan. Antusiasme para peserta pun berlanjut saat sesi tanya jawab seputar peragaan. Banyak peserta yang tertarik dengan penjelasan materi dan mencoba mempraktekkan sendiri di depan temanteman nya dengan dibantu tim dosen.

Beberapa catatan yang muncul pada pelaksanaan Pengabdian Kepada Masyarakat ini yaitu penjelasan praktek yang sedikit terbatas karena penerapan social distancing, sehingga pada saat menjelaskan praktek harus menjaga jarak yang secara tidak langsung cukup kesulitan pada saat memberikan instruksi langsung kepada orang perorangnya. Tetapi hal tersebut tidak mempengaruhi hasil akhir dari pelaksanaan pengabdian ini.

\section{SARAN}

Guna mendukung dan memaksimalkan proses pengelolaan Sumber daya manusia pada usaha kecil yang sudah dirintis oleh Rumah Yatim Piatu Al-Amien Ciater, maka setiap pelaksana Usaha Kecil termasuk pengasuh Rumah Yatim Piatu perlu memperhatikan hal - hal berikut ini:

1. Kontrol Konsistensi, dimana perlu dipersiapkan satu orang yang ditunjuk sebagai Ketua atau penanggung jawab usaha kecil yang selanjutnya bertugas untuk mengendalikan konsitensi pelaksanaan pencatatan keuangan pada proses operasional usaha, dan pengelolaan sumber daya manusia baik harian maupun bulanan dengan cara Kontrol rutin.
2. Pendampingan, dimana perlu diberikan pendampingan secara berkala dalam memastikan pengelolaan sumber daya manusia dilakukan secara tepat dan jujur.

3. Sumber daya manusia yang handal, perlu ditentukan orang yang akan bertindak sebagai pelaksana pengelolaan keuangan dan harus kompeten melalui check kemampuan.

4. Evaluasi, masih harus dilakukan tahapan evaluasi guna memastikan apakah pengelolaan sumber daya manusia ini sudah memberikan dampak yang lebih baik atau bahkan tidak sama sekali, yang selanjutnya dapat diputuskan tindakan perbaikan untuk hasil yang lebih maksimal.

\section{E. DAFTAR PUSTAKA}

Elburdah, R. P., Pasaribu, V. L. D., Rahayu, S., Septiani, F., \& Metarini, R. R. A. (2021). Mompreneur Penopang Perekonomian Keluarga Di Masa Pandemi Covid-19 Dengan Bisnis Online Pada Kelurahan Pondok Benda. Abdi Laksana: Jurnal Pengabdian Kepada Masyarakat, 2(1), 75-82.

Pasaribu, V. L. D., Agrasadya, A., Shabrina, N., \& Krisnaldy, K. (2020). Menjadi Enterpreneur Muda Yang Memiliki Jiwa Leadership Untuk Menghadapi Masa Depan. Abdi Laksana: Jurnal Pengabdian Kepada Masyarakat, 1(1).

Pasaribu, V. L. D., Susanti, F., \& Hartuti, E. T. K. (2019). Memotivasi Siswa dan Siswi SMK Letris Indonesia di Dalam Menentukan Pilihan Untuk Melanjutkan Pendidikan Atau Bekerja Setelah Lulus Sekolah. Jurnal Pengabdian Dharma Laksana, 1(2), 161-172. 


\section{Loyalitas Kreativitas}

\section{Aldi Masyarakat Kreatif}

P-ISSN 2722-2101, E-ISSN 2722-4201

Program Studi Ekonomi Manajemen Universitas Pamulang Jurnal LOKABMAS Kreatif Vol.02,No.02.Juli 2021 Hal.35-43

Email:jurnalkreatif.manajemen@gmail.com
Pasaribu, V. L. D., Sulaiman, S., Sutiman, S., Thaharudin, T., \& Purnomo, B. Y. (2020). Pengenalan Letak Posyandu Terdekat Dikelurahan Pisangan Dengan Manajemen Pemasaran Revolusi 4.0 Untuk Meningkatkan Pengetahuan Masyarakat Letak Dan Fungsi Posyandu Terdekat Pada Kelurahan Pisangan. Dedikasi Pkm, 1(1), 105-110.

Pasaribu, V. L. D., Oktrima, B., Prabowo, B., Arianto, N., \& Haryoko, U. B. (2020). Progam Pendampingan Dan Penyelenggaraan Pendidikan Anak Pada Usia Dini Terhadap Prestasi Belajar Dilingkungan Rt 020 Rw 009. Kel Giri Peni. Kec Wates. Yogyakarta. Jurnal Lokabmas Kreatif, 1(1), 71-75.

Pasaribu, V. L. D., Jannah, M., Fazar, M., Putra, S. P., Monalisa, M., \& Sofa, M. (2021). MENINGKATKAN

PRODUKTIVITAS USAHA DIMASA PANDEMI PADA IBU PKK RT 004/003 KELURAHAN SAWAH BARU CIPUTAT, TANGERANG SELATAN. Abdi Laksana: Jurnal Pengabdian Kepada Masyarakat, 2(2), 295-301.

Pasaribu, V. L. D., Yuniati, H. L., Pranata, R., Sembayu, R., Purba, S. M., \& Nurbayani, T. T. A. (2021). MANAJEMEN KEUANGAN UNTUK MENGHADAPI DAN BERTAHAN DI ERA COVID 19. Jurnal Abdimas Tri Dharma Manajemen, 2(2), 12-18.

Pasaribu, V. L. D., Dwiyatni, A., Sabina, C., Ridwan, M., Gunawan, D. D., \& Noviani, B. C. (2021). EVALUASI PENERAPAN 3M DIMASA PANDEMIC COVID 19. Jurnal Abdimas Tri Dharma Manajemen, 2(2), 54-60.
Aufaizah, A., Irani, C., \& Firtiayani, S. R. (2021). PENGARUH DISPLIN PROTOKOL KESEHATAN TERHADAP PENCEGAHAN PENULARAN VIRUS COVID19. Jurnal Abdimas Tri Dharma Manajemen, 2(2), 91-98.

Priadi, A., Pasaribu, V. L. D., Virby, S., Sairin, S., \& Wardani, W. G. (2020). Penguatan Ekonomi Kreatif Berbasis Sumber Daya Desa Dikelurahan Rempoa. Abdi Laksana: Jurnal Pengabdian Kepada Masyarakat, 1(3), 356-35

Ridwan, 2020 Industry.co.id : Kemenkop dan UKM Dorong Generasi Muda Berkarya Kreatif dan Inovatif

(https://www.industry.co.id/read/61095/ke menkop-dan-ukm-dorong-generasi-mud aberkarya-kreatif-dan-inovatif )

Umum, 2020 kabarbisnis.com : Jumlah wirausaha Indonesia ditargetkan 4 persen pada 2030 (

https://www.kabarbisnis.com/read/289767 1/jumlah-wirausaha-indonesia-ditargetk an-4-persen-pada-2030 )

Brigham, Houston, 2019, Dasar - Dasar Manajemen Keuangan : Salemba Empat, Jakarta

Pasaribu, V. L. D., Syafei, A. N., Farhan, A., 